\title{
IN VITRO STUDY OF THE EFFECT OF ER:YAG LASER IRRADIATION ON THE APICAL SEALING OF DIFFERENT ROOT CANAL SEALERS
}

\author{
ESTUDO “IN VITRO” DO EFEITO DA IRRADIAÇÃO DO LASER ER:YAG NO SELAMENTO \\ APICAL DE DIFERENTES TIPOS DE CIMENTOS OBTURADORES
}

Fernanda Vieira MEDINA ${ }^{1}$, Manoel Damião SOUSA-NETO ${ }^{2}$, Jacy Ribeiro CARVALHO-JUNIOR ${ }^{3}$, Heid Sueli Leme dos SANTOS ${ }^{2}$, Melissa Albanese MEZZENA ${ }^{1}$, Lucas da Fonseca Roberti GARCIA ${ }^{3}$

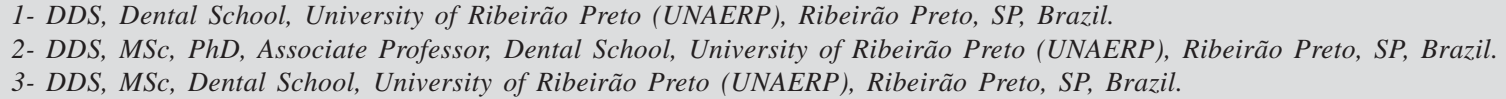

Corresponding address: Heid Sueli Leme dos Santos - Rua Bernardino de Campos, 30 - apto. 1002 - Higienópolis - Cep.: 14015-130 Ribeirão Preto - S.P. - Brazil - Tel.: +55-16-3625-2714 / +55-16-3636-6258 - e-mail: jvicenth@hotmail.com

Received: August 8, 2005 - Modification: January 17, 2006 - Accepted: June 09, 2006

\begin{abstract}
$O$

bjectives: The aim of this study was to determine the effect of Er:YAG laser irradiation used to clean dentinal walls on the apical sealing of root canals filled with different types of sealers. Background Data: Laser application to the dentinal walls removed debris, rendering the root canals free of smear layers and leaving the dentinal canaliculi open. Methods: Sixty-four maxillary canines obtained from laboratory files were instrumented with K-files (Dentsply, Maillefer, Ballaigues, Switzerland) using the crown-down technique, and irrigated with a $0.5 \%$ sodium hypochlorite solution. The specimens were divided into two groups of 32 teeth each. In group I, the teeth were instrumented and irrigated with sodium hypochlorite solution, and divided into four subgroups to be sealed with the different materials (Endofill, N-Rickert, Sealapex and Sealer 26). In group II, the root canals were subjected to Er:YAG laser irradiation $(200 \mathrm{~mJ}, 7 \mathrm{~Hz}$ and $60 \mathrm{~J}$ total energy), followed by root canal sealing as in group I. Results: The data showed lower levels of apical microleakage in the teeth filled with N-Rickert, Sealapex and Sealer 26 cements than in those sealed with Endofill $(\mathrm{p}<0.01)$. No significant difference in microleakage was observed between teeth irrigated only with $0.5 \%$ sodium hypochlorite and those submitted to Er:YAG laser application (p > 0.05). Conclusions: The Er:YAG laser irradiation applied to the root canal walls was not able to prevent apical microleakage.

Uniterms: Endodontics; Laser Er:YAG; Microleakage; Root canal filling materials.
\end{abstract}

\section{RESUMO}

$O$

bjetivos: Avaliou-se a infiltração marginal apical em caninos superiores, obturados com quatro tipos diferentes de cimento, os quais foram imersos em tinta nanquim e mantidos a uma temperatura de $37^{\circ} \mathrm{C}$ por 96 horas, descalcificados em solução de ácido clorídrico a 5\%, desidratados em série crescente de álcoois e diafanizados em salicilato de metila. Métodos: Para isto, 64 dentes de estoque foram instrumentados pela técnica "crown-down”, irrigados com solução de hipoclorito de sódio a 0,5\% e divididos em dois grupos experimentais. Os dentes do Grupo I foram subdivididos em quatro sub-grupos de oito elementos e obturados cada um deles com os cimentos Endofill ${ }^{\circledR}$, N-Rickert ${ }^{\circledR}$, Sealapex ${ }^{\circledR}$ e Sealer $26^{\circledR}$. Os dentes do Grupo II receberam aplicação adicional de laser Er:YAG, tendo seus canais radiculares obturados como aqueles do grupo I. Resultados: A infiltração marginal apical apresentou valores estatisticamente maiores e significantes $(\mathrm{p}<0,01)$, nos dentes obturados com o cimento Endofill $^{\circledR}$, em relação à infiltração ocorrida nos dentes obturados com os cimentos N-Rickert ${ }^{\circledR}$, Sealapex ${ }^{\circledR}$ e Sealer $26^{\circledR}$. Não houve diferença estatística significante $(\mathrm{p}>0,05)$, quanto à infiltração marginal apical, nos dentes do Grupo I, preparados somente com a solução de hipoclorito de sódio a 0,5\%, e naqueles do Grupo II, que foram irradiados com laser Er: YAG. Conclusões: A irradiação de laser Er:YAG aplicada nas paredes do canal radicular não foi capaz de prevenir a infiltração marginal apical.

Unitermos: Endodontia; Laser Er:YAG; Infiltração marginal apical; Materiais restauradores do canal radicular. 


\section{INTRODUCTION}

The hermetic sealing of root canals is of central importance in successful endodontic therapy. This step consists of sealing the entire root canal system with biologically tolerated materials with good physicochemical properties, resistant to microleakage and capable of creating an appropriate environment for tissue regeneration ${ }^{5}$ So far, however, no material has shown all these desired properties. Thus, to a greater or lesser extent, apical microleakage has continued to occur in endodontic seals $7,6,4,2,1,13$.

Fachin, et al. ${ }^{6}$ (1995) determined the sealing ability of FillCanal, Sealer 26 and N-Rickert endodontic cements in teeth filled by the lateral gutta-percha condensation technique. Apical microleakage was identified after the treated teeth were immersed in Indian ink for 72 hours and then cleaned. The lowest levels of apical microleakage were observed when the FillCanal cement had been used, followed by the N-Rickert and Sealer 26 cements.

Apical microleakage is characterized by the flow of tissue fluids through the interface between root canal walls and filler materials, which allows for bacterial proliferation and, consequently, leads to irritation of the tooth-supporting tissues. In turn, this causes inflammation especially in the periapical region ${ }^{13}$.

Among the chemical solutions used nowadays as biomechanical primers in root canals, different concentrations of sodium hypochlorite are the most commonly used. Worldwide, the product is valued for its clearing, organic tissue dissolution, and saponifying properties; as well as for its capacity to transform amines into chloramines, and to work as a deodorant and an antibacterial agent. Senia, et al. ${ }^{11}$ (1971) showed that 5\% sodium hypochlorite is efficient in cleaning root canals, except for the apical three millimeters.

Takeda et al. ${ }^{17}$ (1998) used scanning electron microscopy to study the efficiency of Er:YAG laser to debride previously instrumented root canal walls. The authors tested the laser at 1 and $2 \mathrm{~W}$ powers and a third, non-irradiated group of teeth was used as control. The results showed that the laser application at both power levels debrided the root canals and left the dentinal canaliculi open. In contrast, smear layers were found at all canal levels in the control group, which obstructed the dentinal canaliculi.

The aim of the present study was to determine the effect of Er:YAG laser irradiation onto the dentinal walls on apical microleakage of root canals filled with different types of sealers by the lateral condensation technique.

\section{MATERIALAND METHODS}

Sixty-four intact human maxillary canines kept by the Dental Research Laboratory of University of Ribeirão Preto were used in this study. The teeth were immersed in $0.1 \%$ thymol at $9^{\circ} \mathrm{C}$, and then washed under running water for 24 hours to remove traces of the thymol solution.

The teeth were cross-sectioned along their axes, leaving a root remnant of $14 \mathrm{~mm}$. Pulp tissue was removed by abundant irrigation with $0.5 \%$ sodium hypochlorite. Odontometry was performed by introducing No. $10 \mathrm{~K}$-files (Dentsply, Maillefer, Ballaigues, Switzerland) inside the root canal until their tip could be seen in the apical foramen, followed by a $1 \mathrm{~mm}$ withdrawal, and the measurement of its actual length. Root canals were instrumented using the crown-down technique. The root canals were irrigated with $0.5 \%$ sodium hypochlorite at each instrument change. Following the biomechanical preparation of the root canals, the teeth were randomly divided into two experimental groups of 32 teeth each. Teeth in Group I were submitted to final irrigation with $10 \mathrm{ml}$ deionized distilled water. Group II teeth were further subjected to the application of Er:YAG laser rays (7-Hz frequency, $200 \mathrm{~mJ}, 300$ pulses and $60 \mathrm{~J}$ total energy) and were then irrigated with deionized distilled water.

Each experimental group was divided into four subgroups of eight teeth each. The canals in each subgroup were filled with the following cements: Endofill ${ }^{\circledR}$ (Dentsply, Herpo, Petróplis, RJ), consisting of zinc oxide and eugenol; N-Rickert (Inodon, Porto Alegre, RS) consisting of zinc oxide and eugenol; Sealapex ${ }^{\circledR}$ (Kerr, Romulus, USA), consisting of calcium hydroxide; and Sealer $26^{\circledR}$ (Dentsply-Brasil, Petrópolis, RJ), consisting of epoxy resin. All teeth were filled using the lateral gutta-percha condensation technique. After being sealed, the teeth were immersed in distilled water and incubated at $37^{\circ} \mathrm{C}$ for a period equivalent to three times the time required to harden the cement according to the manufacturer. Then, the teeth were removed and dried.

The external surfaces of teeth were rendered impermeable through the application of two layers of cyanoacrylate ester, except for the apical two millimeters. After the coating had dried, the teeth were immersed in Indian ink and kept at $37^{\circ} \mathrm{C}$ for 96 hours. The teeth were then washed under running water for 1 hour and dried. The cyanoacrylate was removed from the root canal surface with a No. 15 surgical blade. The teeth were immersed in a 5\% $\mathrm{HCl}$ solution for debridement, and the solution was changed at every 6 hours. The teeth were dehydrated in increasingly stronger alcohols (70, 85, 96 and 100\%) for 4 hours each. They were then cleared in methyl salicylate.

Apical microleakage was assessed them under a $2.5 \mathrm{x}$ magnification optical microscope (Measuroscope, Nikon ${ }^{\circledR}$, Japan) using software Scion Image for Windows ${ }^{\circledR}$.

The data concerning the used treatments and sealants were analyzed through ANOVA. Apical microleakage levels for different cements were compared using Tukey’s test.

\section{RESULTS}

The data on apical microleakage for the teeth treated with $0.5 \%$ sodium hypochlorite (Group I), and with $0.5 \%$ sodium hypochlorite plus Er:YAG laser irradiation (Group II) before root canals were filled with the Endofill, N-Rickert, Sealapex and Sealer 26 cements are shown in Tables 1 and 2. 
Variance analysis revealed a significant difference ( $\mathrm{p}<$ 0.01 ) between the various cements used, but not between root canal treatments prior to sealing $(\mathrm{p}>0.05)$. The interaction between treatments and cements showed significant differences at the $5 \%$ level.

No significant differences in apical microleakage were observed between N-Rickert, Sealapex and Sealer 26 (p > 0.01 ), while significantly higher leakage was found when Endofill cement was used $(\mathrm{p}<0.01)$. None of the cements used, nor any of the treatments applied to the root canal walls, was able to prevent apical microleakage totally.

\section{DISCUSSION}

The clearance method was used in this study to analyze apical sealing as determined by microleakage. This is a simple, easy and inexpensive technique, which allows, according to Hasselgren and Tronstad ${ }^{7}$ (1975), three-dimensional viewing of the tooth. Like in other studies, some factors were taken into account to prevent leakage of the marker agent between dental structures, such as the coating of the external root surfaces with cyanoacrylate ester for proofing. Indian ink was used to show the level of microleakage because it is resistant to acids, alcohols and methyl salicylate.

Apical microleakage in the root canal is a complex phenomenon due to the interplay of numerous factors such as the anatomy of the root canal, properties of the irrigating solution, physicochemical characteristics of sealants, and different sealing techniques ${ }^{13}$.

Since no ideal filling material is currently available, special attention should be paid to the biomechanical preparation of the tooth, for which different irrigating solutions are recommended and new devices enter the endodontic arsenal, all of which are used as support. It is the interdependence of one treatment step on another that has to be attended to in order for the final results to be optimal.

Almost half a century after the discovery of laser beams, their use has become the focus of frequent studies. Laser application combined with irrigating solutions permits the removal of smear layer from the dentinal walls ${ }^{9,10}$, thereby enhancing the adhesion of epoxy resin cements. However, the results obtained in this study show no significant statistical difference between the two types of treatment applied to the dentinal walls ( $0.5 \%$ sodium hypochlorite and $0.5 \%$ sodium hypochlorite plus final irradiation with Er:YAG laser).

Although Sousa-Neto ${ }^{14}$ (2005) has reported that smear layer removal with Er:YAG laser increased the adhesion of epoxy resin cements, no decrease in microleakage was reported in teeth filled with Sealer 26 cement in the present study. On the other hand, Pécora, et al. ${ }^{9}$ (1999) obtained better permeability results when Er:YAG laser was applied in combination with distilled water in comparison to the use of a $1 \%$ sodium hypochlorite solution, as also reported in the study of Sousa-Neto, et al. ${ }^{12}$ (2002).

The two types of root canal wall treatment were prone to apical microleakage, as determined by Indian ink penetration in vitro. The Er:YAG laser application using the parameters indicated in this study did not reduce apical microleakage when compared to $0.5 \%$ sodium hypochlorite. This fact confirms the findings of Mello, et al. ${ }^{8}$ (2004). Analyses using Tukey's test revealed the superiority of the N-Rickert, Sealapex and Sealer 26 cements over Endofill to provide apical seals. The first three cements produced lower levels of apical microleakage.

\section{CONCLUSION}

The Er:YAG laser irradiation applied to the root canal walls was not able to prevent apical microleakage.

TABLE 2- Tukey test: between cements

\begin{tabular}{llc} 
Cement & Mean & Critical value $(K=0.01)$ \\
\hline Endofill & $0.50375 *$ & \\
N-Rickert & $0.19000 \bullet$ & 0.21276 \\
Sealapex & $0.22938 \bullet$ & \\
Sealer 26 & $0.25000 \bullet$ & \\
\hline
\end{tabular}

TABLE 1- Means (in $\mathrm{mm}$ ) and standard deviation of the specimens submitted to two different treatments and filled with four types of cements

\section{Treatment}

\section{Cement}

N-Rickert

Sealapex

Sealer 26

\begin{tabular}{|c|c|c|c|c|}
\hline $0.5 \% \mathrm{NaOCl}$ & $0.50 \pm$ & $0.20 \pm$ & $0.23 \pm$ & $0.26 \pm$ \\
\hline & 0.18 & 0.09 & 0.07 & 0.13 \\
\hline $0.5 \% \mathrm{NaOCl}+$ & $0.51 \pm$ & $0.18 \pm$ & $0.23 \pm$ & $0.24 \pm$ \\
\hline Er:YAG & 0.15 & 0.02 & 0.10 & 0.10 \\
\hline
\end{tabular}




\section{REFERENCES}

1- Antonopoulos K G, Attin T, Hellqig E. Evaluation of the apical seal of root canal fillings with different methods. J Endod. 1998;24(10):655-8.

2- Arruda M P, Carvalho-Júnior J R, Guerizoli D M Z, Pécora J D, Sousa-Neto M D. Evaluation of the apical microleakage, related to the collocation of sealers cements in the interior of root canals. Pesqui Odontol Bras. 2000;14(suppl).

3- Cohen S, Burns R C. Pulp way. 6. ed. Rio de Janeiro: Guanabara Koogan; 1994.

4- Dalat D M, Onal B. Apical leakage of a new glass ionomer root canal sealer. J Endod. 1998;24(3):161-3.

5- De Almeida W A, Leonardo M R, Tanomaru Filho M, Silva L A B. Evaluation of apical sealing of three endodontic sealers. Int Endod J. 2000;33(1):25-7.

6- Fachin E V F, Sperb M N, Kohler T M P. A influência de diferentes cimentos de obturação do canal na infiltração apical. Rev Fac Odontol Porto Alegre. 1995;36(1):24-6.

7- Hasselgren G, Tronstad L. The use of transparent teeth in the teaching of preclinical endodontics. J Endod. 1975;8:25-34.

8- Mello, I, Robazza, C R C, Antoniazzi, J H. Influence of Er:YAG laser irradiation on apical sealing of four different sealers. Braz Dent J. 2004;15(3):190-3.

9- Pécora J D, Brugnera JR A, Cussioli A L, Silva R S, Zanin F. Dentin root canal wall permeability evaluation after instrumentation and Er:YAG laser application. In: ANNUAL MEETING AMERICAN SOCIETY FOR LASER MEDICINE AND SURGERY, 19., Orlando; 1999. Abstract. Orlando.

10- Pécora J D, Saquy P C, Sousa-Neto M D, Woelfel J B. Root form and canal anatomy of maxilary first premolars. Braz Dent J. 1991;2(2):87-94.

11- Senia E S, Marshall F J, Rosen S. The solvent action of sodium hypochlorite on pulp tissue of extracted teeth. Oral Surg Oral Med Oral Pathol. 1971;31(1):96-103.

12- Sousa-Neto M D, Marchesan M A, Pécora J D, Brugnera-Júnior A, Silva-Sousa Y T C, Saquy P C. Effect of Er:YAG laser on adhesion of root canal sealers. J Endod. 2002;28:185-7.

13- Sousa-Neto, M D, Passarinho-Neto, J G, Carvalho-Junior, J R, Cruz-Filho, A M, Pécora, J D, Saquy, P C. Evaluation of the effect of EDTA, EGTA and CDTA on dentin adhesiviness end microleakage with different root canal sealers. Braz Dent J. 2002;13:123-8.

14- Sousa-Neto, M D, Silva Coelho, F I, Marchesan M A, Alfredo, E, Silva-Sousa Y T C. Ex vivo study of the adhesion of an epoxy-based sealer to human dentine submitted to irradiation with Er: YAG and Nd: YAG lasers. Int Endod J. 2005;38(12):866-70.

15- Spanó J C E, Barbin E L, Santos T C, Guimarães J F, Pécora J D. Solvent action of sodium hypochlorite on bovine pulp and physicochemical properties of resulting liquid. Braz Dent J. 2001;12:154-7.

16- Takeda F H, Harashima T, Kimura Y, Matsumoto K. Comparative study about the removal of smear layer by three types of Lasers devices. J Clin Laser Med Surg. 1998;16(2):117-22.

17- Takeda F, Harashima T, Kimura Y, Matsumoto K. Efficacy of Er:YAG laser irradiation in removing debris and smear layer on root canal walls. J Endod. 1998;24(8):548-51. 